\title{
PROPAGATION OF MAGNOLIA BIONDII PAMP THROUGH STEM CUTTINGS USING EXOGENOUS HORMONES
}

\author{
KHAN, M. A. ${ }^{1}$ - WANG, Y. ${ }^{1}-$ Uddin, S. $^{3}-$ MuHAMmad, B. ${ }^{1}$-BAdShaH, M. T. ${ }^{4}-$ KHAN, D. ${ }^{5}-$ \\ MUNEER, M. A. ${ }^{2}-$ MUNIR, M. Z. ${ }^{3}$-JIA, Z. K..$^{*}$ \\ ${ }^{I}$ Ministry of Education Key Laboratory of Silviculture and Conservation, Beijing Forestry \\ University, Beijing 100083, China \\ ${ }^{2}$ College of Grassland Science, Beijing Forestry University, Beijing 100083, China \\ ${ }^{3}$ College of Biological Sciences and Technology, Beijing Forestry University, Beijing 100083, \\ China
}
${ }^{4}$ Research Center of Forest Management Engineering of National Forestry and Grassland Administration, Beijing Forestry University, Beijing 100083, China

${ }^{5}$ College of Forestry, Beijing Forestry University, Beijing 100083, China

*Corresponding author

e-mail: jiazk@bjfu.edu.cn; phone: +86-10-6233-7098

(Received $30^{\text {th }}$ Sep 2019; accepted $8^{\text {th }}$ Jan 2020)

\begin{abstract}
The effects of exogenous hormones were optimized with different morphological characteristics of cuttings (cuttings from the different crown position, cuttings length and cuttings soaking time) for rooting in successive experiments to enhance the efficiency of vegetative propagation of Magnolia biondii Pamp. For this purpose, a series of experiments were conducted in a greenhouse. Application of exogenous hormones at different concentrations significantly affected the rooting of Magnolia biondii Pamp cuttings, we found that Indole-3-butyric acid (IBA) at $750 \mathrm{mg} / \mathrm{L}$ resulted in the highest rooting rate $(78.89 \%) .750 \mathrm{mg} / \mathrm{L}$ IBA was further applied in all other experiments. Stem cuttings collected from the lower position of the plant crown showed higher rooting rate $(79.67 \%)$ than upper and middle position. Hence, IBA $750 \mathrm{mg} / \mathrm{L}$ and cuttings collected from the lower position of the crown were further evaluated under different soaking times $(60,120,240,360 \mathrm{~min})$ and found that $120 \mathrm{~min}$ soaking time significantly affected the rooting and achieved the highest rooting rate of $80.67 \%$. In the last step of optimization of key factors that affect the propagation of Magnolia biondii Pamp, we checked the effect of cutting length by applying all the previously determined factors (IBA $750 \mathrm{mg} / \mathrm{L}$, lower crown position, $120 \mathrm{~min})$. We found longer cuttings $(21-25 \mathrm{~cm})$ gave the highest rooting rate $(83.11 \%)$ rather than short cuttings. Hence, we found that optimal method includes IBA $750 \mathrm{mg} / \mathrm{L}$, the lower part of the crown, 120 min of soaking time, and longer cuttings for vegetative propagation of Magnolia biondii Pamp to produce high-quality planting stock material.
\end{abstract}

Keywords: Magnolia biondii Pamp, vegetative propagation, exogenous hormones, crown position, soaking time, cuttings length

\section{Introduction}

Magnolia biondii Pamp belonging to family Magnoliaceae, is a deciduous and popular ornamental species distributed in northern China (Coombes, 2014). This species was discovered and introduced to the western hemisphere more than 70 years ago (Coombes, 2014). Its flowering time is from late winter to early spring before leaf growth and blooms single at the top of the branches, each flower has three sepals and six petals which shaped like spoons showing purplish-red color on the base and whitish on the rest of the part. Leaves of Magnolia biondii Pamp are unifoliate alternate, the leaf 
blade is oblong-lanceolate or ovate-lanceolate glabrous on both sides. It grows up to $12 \mathrm{~m}$ and shows the best performance in sandy and loamy soil on above $600 \mathrm{~m}$ elevation.

Great differences in the rooting ability of cuttings exist among species and cultivars (Kester et al., 1990). Stem cuttings of some cultivars root so readily that the simplest facilities and care give high rooting percentages (Kester et al., 1990). On the other hand, cuttings of many cultivars or species have yet to be rooted (Kester et al., 1990). Cuttings of some difficult cultivars can be rooted only if specific influencing factors are taken into consideration and if the cultivars are maintained at the optimum condition (Kester et al., 1990). All the species neither propagate easily nor do they respond similarly to a single method of propagation (Kester et al., 1990). There is a lack of suitable propagation method for Magnolia biondii Pamp species on large scale through stem cuttings, but there are some published reports available in Magnolia biondii Pamp species (Zhang et al., 2003; Wang et al., 2017). However, these studies did not demonstrate a proper protocol for its propagation. So, we here optimized a complete propagation scheme for Magnolia biondii Pamp species.

On the other hand, the propagation method with stem cuttings is recommended for quicker establishment faster production (Kester et al., 1990). Adventitious rooting is a critical step in vegetative propagation because cutting do not form roots or they form poor quality root system (Villacorta-Martín et al., 2015). The formation of adventitious roots in mini-cuttings includes the formation of meristematic cells niches (i.e., initial cells and/or target cells), which are dependent on external and internal factors (Dettmer et al., 2009; Papp and Plath, 2011). Reproduction through cuttings is reproduction made by use of a piece taken from the stem, root, or leaf of a plant, cuttings are put in suitable environmental conditions and are forced to form roots (Sevik and Turhan, 2015). Adventitious roots are distinct from lateral roots in that they are formed from any tissue that is not a root, such as leaves and stems, naturally or in response to altered growth environments (Bellini et al., 2014; Geiss et al., 2009). Adventitious rooting is an essential step in the vegetative propagation of economically important horticultural and woody species (Geiss et al., 2009); therefore, it is very important to enhance their growth by using different plant growth regulators.

All classes of exogenous hormones auxin, cytokinin, gibberellin, ethylene, and abscisic acid, and ancillary compounds such as growth retardants/inhibitors, polyamines, and phenolics influence root initiation either directly or indirectly (Davis and Haissig, 1990). Exogenous hormones are commonly used in plant propagation methods to enhance the root development, number, and quality of roots. Generally, a high or low concentration of exogenous hormones supplemented in the propagation method could promote or inhibit cell growth. In several species, rooting competence has been associated with the presence of inductive factors such as exogenous hormones. Auxin and gibberellin particularly IBA, NAA, IAA, and GGR $_{6}$ have been reported to induce rooting in many of the plant species with varied success. The response of different exogenous hormones to percent success varied from species to species, changing physiological and environmental conditions. Most of the researchers have reported IBA and NAA as better growth regulators than others for inducing rooting in cuttings due to their stable nature. During the propagation through cuttings, there are some other factors that affect the rooting like environmental conditions, age of stock, rooting media, and concentration of exogenous hormones (Kester et al., 1990). Among 
all these factors, the concentration of exogenous hormones contributes significantly towards successful propagation.

Rooting ability of different plant species through stem cuttings can also be affected by the several factors such as the crown position of the parent plant, length of the cuttings and soaking time of the cuttings into the exogenous hormones (Kester et al., 1990; Leakey, 1983; Azamal and Mohinder, 2000; Elhaak et al., 2015). However, cuttings characteristics and these factors on the induction of rooting varies from species to species (Harrison-Murray and Knight, 1997). So, it imperative to include the characteristics of the cutting for the effective clonal propagation of plants (Luz et al., 2007; Lekha and Lalji, 2010).

Propagation through cuttings needs more concentration and scientific knowledge. Propagator need to keep thorough records of procedures and the seasonal condition of plant materials and conduct small tests to achieve optimum success for their particular propagation system (Dirr, 1989). Treatment of the cuttings with exogenous hormones, the size of the cuttings, humidity and bottom heat is desirable for rapid rooting. Cuttings must be taken from nutritionally healthy stock plants (Davies Jr, 1988). The propagation material for hardwood cuttings should be collected from healthy, fairly vigorous stock plants growing in full sunlight (Kester et al., 1990). All these factors and substances cannot be used without scientific knowledge, experiments and proper research. For this purpose and to give a proper scheme and scientific method to propagate Magnolia biondii Pamp, different experiments in the greenhouse and in the laboratory have been done. Despite being so special ornamental and medicinal features, this species got no attention for its propagation and research. Magnolia Biondii Pamp has not yet any published reports that demonstrate the potential for successful propagation.

The objectives of our study were to evaluate the effects of exogenous hormone type; soaking time on the rooting success; effect of the position of the stock plant crown and length of cuttings; and establish a proper cutting propagation scheme for Magnolia biondii Pamp to produce more elite clone plants.

\section{Materials and methods}

\section{Plant material and experiment site}

The plant material of Magnolia biondii Pamp cuttings were obtained from the sevenyears-old mother plants located at the Silviculture test station of Beijing Forestry University at Jiufeng, Beijing in late June. The experiment was conducted in the greenhouse (temperature: $20-30{ }^{\circ} \mathrm{C}$, relative humidity: about $80 \%$ ) located near the test station in 2018-2019. The geographical coordinates of the test station are 40.3054" N and 116.05045" E (Fig. 1). This area has temperate humid monsoon climate zone with hot, variable rainy summers and dry cold winters. The average annual temperature is $12.5^{\circ} \mathrm{C}$ with an accumulating temperature of $42{ }^{\circ} \mathrm{C}$, and the number of annual sunshine hours is $2662 \mathrm{~h}$.

\section{Experiment-1: effect of exogenous hormones on the rooting}

A complete randomized block design was set using six different concentrations (250, $500,750,1000,1250$, and $1500 \mathrm{mg} / \mathrm{L}$ ) of four different plant growth regulators $\left(\mathrm{GGR}_{6}\right.$, NAA, IBA, IAA) along with water-treated control group $(0 \mathrm{mg} / \mathrm{L})$ with each plant growth 
regulator. A total of 28 treatments were performed in each replication and the experiment was replicated three times. The layout of the experiment was as follows (Fig. 2).

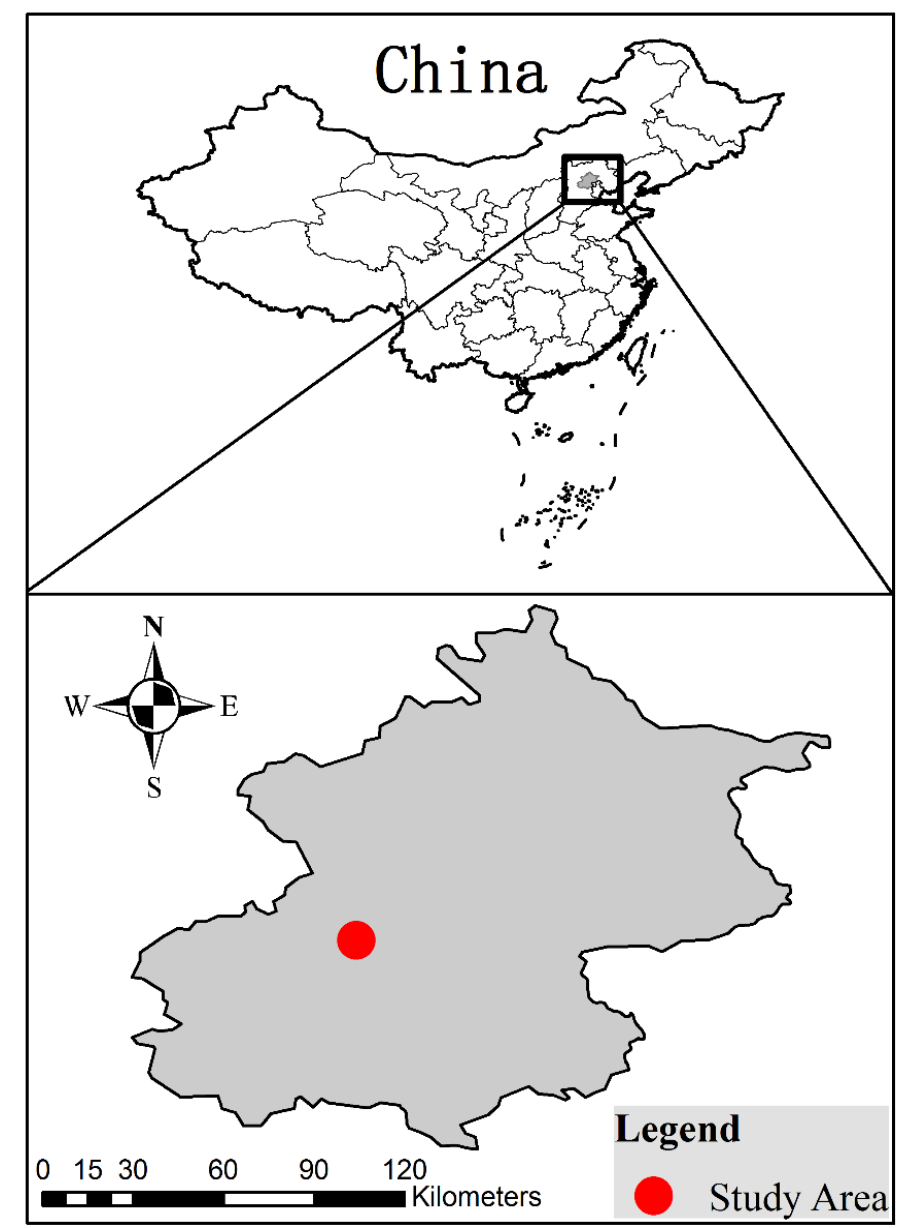

Figure 1. Red point in the map shows the study area; Silviculture Test Station of Beijing Forestry University, Jiufeng Beijing, China

\begin{tabular}{|c|c|c|c|c|c|c|c|c|c|c|c|c|c|c|c|c|c|c|c|c|c|c|c|c|c|c|c|}
\hline \multicolumn{28}{|c|}{ Replication-1 } \\
\hline \begin{tabular}{|l|}
1 \\
\end{tabular} & 2 & 3 & 4 & 5 & 6 & 7 & 8 & 9 & 10 & 11 & 12 & 13 & 14 & 15 & 16 & 17 & 18 & 19 & 20 & 21 & 22 & 23 & 24 & 25 & 26 & 27 & 28 \\
\hline \begin{tabular}{|l|} 
A1 \\
\end{tabular} & 83 & 07 & 02 & 81 & 04 & 03 & $\mathrm{Cl}$ & 87 & 82 & 06 & OS & A2 & 06 & $\mathrm{AB}_{3}$ & $A 7$ & os & $A^{A G}$ & $\mathrm{CS}$ & 6 & 04 & a & $c_{2}$ & AS & $\mathrm{c}_{3}$ & 01 & ${ }^{A 6}$ & $\mathrm{cA}$ \\
\hline \multicolumn{28}{|c|}{ Replication-2 } \\
\hline \begin{tabular}{|l|}
1 \\
\end{tabular} & 2 & 3 & 4 & 5 & 6 & 7 & 8 & 9 & 10 & 11 & 12 & 13 & 14 & 15 & 16 & 17 & 18 & 19 & 20 & 21 & 22 & 23 & 24 & 25 & 26 & 27 & 28 \\
\hline \begin{tabular}{|l|}
$A 1$ \\
\end{tabular} & $A 2$ & a & 02 & A7 & CA & C) & 01 & 87 & 82 & $\mathrm{Ab}^{-}$ & OS & $\mathrm{C}_{2}$ & 06 & $\overline{c s}$ & 07 & es & $\overline{A 4}$ & AS & $\overline{66}$ & os & $\mathrm{C}^{1}$ & 03 & $c_{4}$ & $\mathrm{AB}^{3}$ & 83 & 06 & 81 \\
\hline \multicolumn{28}{|c|}{ Replication-3 } \\
\hline \begin{tabular}{|l|}
1 \\
\end{tabular} & 2 & 3 & 4 & 5 & 6 & 7 & 8 & 9 & 10 & 11 & 12 & 13 & 14 & 15 & 16 & 17 & 18 & 19 & 20 & 21 & 22 & 23 & 24 & 25 & 26 & 27 & 28 \\
\hline $\mathrm{CA}_{4}$ & $A G$ & 01 & $\mathrm{C}_{3}$ & AS & $c_{2}$ & c & 84 & $\infty 6$ & $\mathrm{CS}$ & A4 & OSS & A7 & $\mathrm{AB}^{\mathrm{B}}$ & DE & $A 2$ & 05 & 06 & 82 & 87 & $\mathrm{C} 1$ & 03 & 04 & 81 & 02 & 07 & 03 & \begin{tabular}{|l} 
A1 \\
\end{tabular} \\
\hline
\end{tabular}

Figure 2. Here A represents $G G R_{6}, B$ represents $N A A, C$ represents $I B A$, and $D$ represents IAA. 1-7 represents different concentrations of plant growth regulator in which 1 represents $0 \mathrm{mg} / \mathrm{L}$ (control), 2 represents $250 \mathrm{mg} / \mathrm{L}, 3$ represents $500 \mathrm{mg} / \mathrm{L}, 4$ represents $750 \mathrm{mg} / \mathrm{L}$, 5 represents $1000 \mathrm{mg} / \mathrm{L}, 6$ represents $1250 \mathrm{mg} / \mathrm{L}$ and 7 represents $1500 \mathrm{mg} / \mathrm{L}$ 
Culture of Magnolia biondii Pamp stems cuttings were established in the greenhouse. The environment of the greenhouse was uniform and did not cause errors in the results of each block. The soil beds consisted of the river sand. The length and width of the soil bed were $6 \times 1.5 \mathrm{~m}$ and depth was $15 \mathrm{~cm}$. Before shifting the treated cuttings into the beds, the rooting media was fully disinfected by $0.2 \%$ potassium permanganate solution (fungicide). The soil was pulverized and misted well. Softwood branches were brought from the mother trees in the morning and converted into the desired stem cuttings. The prepared cuttings were washed under running tap water several times and then shifted into the carbendazim solution for $15 \mathrm{~min}$ to disinfect before sticking in the soil. Exogenous hormones concentrations were prepared and cuttings were kept into the concentrations for $30 \mathrm{~min}$ and then cuttings were implanted into the soil according to the proposed experimental design. Cuttings were irrigated through a misting shower system.

\section{Experiment-2: Effect of stem cuttings collected from the different positions of the tree crown}

This experiment was conducted to check the effect of the crown position of the stock plant on the rooting. For this experiment shoots for the preparation of cuttings were collected from three different crown positions (upper, middle, lower). These cuttings were treated with IBA $750 \mathrm{mg} / \mathrm{L}$ (selected from experiment-1). Thirty cuttings per treatment were used and the experiment was repeated three times.

\section{Experiment-3: Effect of soaking time of the cuttings into the exogenous hormone}

In this experiment, we evaluated the effect of soaking time of cuttings into the IBA $750 \mathrm{mg} / \mathrm{L}$ with the lower crown position that was selected in the first and second experiments respectively. Prepared cuttings were soaked for four different time periods i.e., $60 \mathrm{~min}, 120 \mathrm{~min}, 240 \mathrm{~min}$ and $360 \mathrm{~min}$. Thirty cuttings per treatment were prepared and the experiment was replicated three times.

\section{Experiment-4: Effect of cuttings size on the rooting}

In this experiment, four classes of stem cuttings length were prepared to select the best cutting length for the propagation of Magnolia biondii Pamp. Four different classes of cuttings i.e., $5-10 \mathrm{~cm}, 11-15 \mathrm{~cm}, 16-20 \mathrm{~cm}$ and $21-25 \mathrm{~cm}$ were prepared from the lower crown position and soaked into IBA $750 \mathrm{mg} / \mathrm{L}$ for $120 \mathrm{~min}$. Thirty cuttings per treatment were used and the experiment was repeated three times.

\section{Analytical measurements}

After the completion of experiments, cuttings were carefully uprooted and rinsed with the water. First of all, the number of roots of each cutting was measured by counting. The rooting rate was measured by Equation 1:

$$
\text { Rooting rate }=\frac{\text { Number of rooted cuttings }}{\text { Total number of cuttings }} \times 100
$$

For the measurement of total root length, root diameter, and root volume, roots were scanned and these scanned images were further analyzed with WinRHIZO Pro 2013a software to measure aforesaid root parameters. 


\section{Statistical analysis}

Experiments were performed by following Complete Randomized Block Design (CRBD). Data were analysed using Analysis of Variance (ANOVA) method and least significant difference test $\left(\mathrm{LSD}_{0.05}\right)$ by using IBM SPSS Statistics v20. Graphs were prepared using Origin Pro 2018 software.

\section{Results}

\section{Effect of exogenous hormones on the rooting}

The macro propagation methods play an important role in the improvement of many plant species and have been discovered for the propagation of many valuable species, particularly the ornamental, aesthetical, rare and endangered species (Jamir et al., 2016). Propagation system through stem cuttings can be a significant step in vegetative propagation. This is the first research-based report which established a scientific method for the proliferation of roots from the stem cuttings of Magnolia biondii Pamp using different exogenous hormones.

The rooting rate was determined in term of rooting percentage. In this study, it was found that among different exogenous hormones, IBA with its different concentrations has a more obvious trend. With the increase in the concentration of IBA rooting rate increased and reached to its peak value and then decreased continuously with the increase in concentration. It showed the highest rooting rate at the concentration of $750 \mathrm{mg} / \mathrm{L}$ about $78 \%$ in comparison with other exogenous hormones i.e., GGR 6 , NAA, IAA and control. Statistically significant differences $(F(6,14)=11.5, p=0.0001))$ were found for IBA. While, GGR 6 , NAA, and IAA also revealed the highest rooting rate at $750 \mathrm{mg} / \mathrm{L}(34 \%), 1000 \mathrm{mg} / \mathrm{L}(63 \%)$, and $1250 \mathrm{mg} / \mathrm{L}(43 \%)$ respectively. Moreover, there were also found statistically significant differences for all these exogenous hormones among different concentrations. Compared to all other exogenous hormones and their concentrations, $\mathrm{GGR}_{6}$ performed very low rooting rate. IAA performed better than GGR $_{6}$, but with comparison to NAA and IBA, IAA has a very low rooting rate. So, IBA $750 \mathrm{mg} / \mathrm{L}$ comparatively performed best than other exogenous hormones (Table 1).

Table 1. Effect of exogenous hormones on the rooting rate

\begin{tabular}{c|c|c|c|c}
\hline Conc. $(\mathbf{m g} / \mathbf{L})$ & GGR6 $_{\mathbf{6}}$ & NAA & IBA & IAA \\
\hline 0 & $24.44 \pm 2.60^{\mathbf{a b}}$ & $25.56 \pm 0.88^{\mathbf{d}}$ & $32.22 \pm 1.45^{\mathbf{e}}$ & $17.78 \pm 0.33^{\mathbf{b}}$ \\
250 & $30.00 \pm 1.15^{\mathbf{a b}}$ & $47.78 \pm 0.88^{\mathbf{b c}}$ & $50.00 \pm 1.53^{\mathbf{c d}}$ & $30.00 \pm 1.53^{\mathbf{a b}}$ \\
500 & $24.44 \pm 0.88^{\mathbf{a b}}$ & $44.44 \pm 1.20^{\mathbf{c}}$ & $56.67 \pm 2.08^{\mathbf{b c}}$ & $35.56 \pm 4.18^{\mathbf{a b}}$ \\
750 & $34.44 \pm 0.88^{\mathbf{a}}$ & $61.11 \pm 1.20^{\mathbf{a}}$ & $78.89 \pm 1.45^{\mathbf{a}}$ & $36.67 \pm 3.51^{\mathbf{a b}}$ \\
1000 & $18.89 \pm 0.33^{\mathbf{b c}}$ & $63.33 \pm 0.58^{\mathbf{a}}$ & $67.78 \pm 1.33^{\mathbf{a b}}$ & $42.22 \pm 1.67^{\mathbf{a}}$ \\
1250 & $8.89 \pm 0.88^{\mathbf{c}}$ & $56.67 \pm 0.58^{\mathbf{a b}}$ & $50.00 \pm 1.00^{\mathbf{c d}}$ & $43.33 \pm 0.58^{\mathbf{a}}$ \\
1500 & $7.78 \pm 0.33^{\mathbf{c}}$ & $43.33 \pm 1.15^{\mathbf{c}}$ & $38.89 \pm 0.67^{\mathbf{d e}}$ & $27.78 \pm 0.67^{\mathbf{a b}}$ \\
\hline
\end{tabular}

Values followed by the same letters show non-significant differences while different letters show significant differences $\left(\mathrm{LSD}_{0.05}\right)$ for each hormone at different concentrations. Data are mean $\pm \mathrm{SE}$

Different plant growth regulators resulted in significant differences in the mean number of roots per cutting. The number of roots was significantly $(P<0.05)$ effected 
by exogenous hormones. IBA $750 \mathrm{mg} / \mathrm{L}$ had the highest number of roots ( 20 pcs) which significantly differed with its other concentrations, control, and other exogenous hormones. Cuttings treated with the different concentrations of NAA had also significant $(\mathrm{F}(6,14)=17.9, p=0.0000)(\mathrm{P}<0.05))$ results. NAA $750 \mathrm{mg} / \mathrm{L}$ and NAA $1000 \mathrm{mg} / \mathrm{L}$ showed non-significant results i.e. 12 pcs and 11 pcs respectively but, they were significantly higher than its control $(2 \mathrm{pcs})$. IAA did not show good results compared to IBA and NAA. IAA $1000 \mathrm{mg} / \mathrm{L}$ had the highest number of roots (5 pcs) compared to its other concentrations. Generally, GGR 6 had a very low mean number of roots. The highest mean number of roots within the $\mathrm{GGR}_{6}$ concentrations were found at $750 \mathrm{mg} / \mathrm{L}$ (3 pcs) which did not have a much difference compared to its control (Fig. 3a).
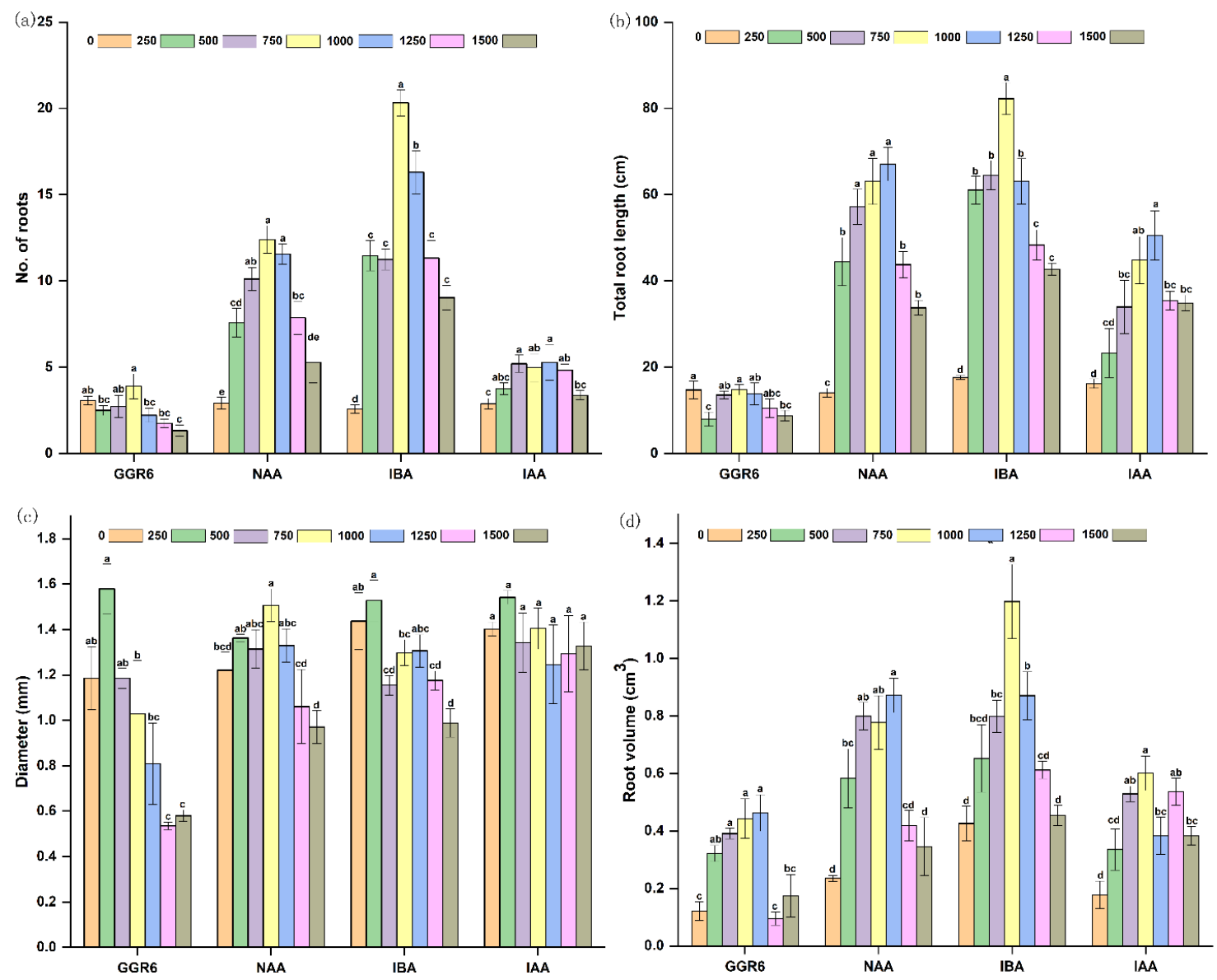

Figure 3. Effect of different plant growth regulators on (a) the average number of roots per cutting; (b) mean total root length per cutting; (c) mean root diameter per cutting; $(d)$ mean root volume per cutting at different exogenous hormones and their different concentrations.

Alphabets on the top of each bar showing the $L S D_{0.05}$ difference. The same letters show the nonsignificant differences, while the different letters show the significant differences between different concentrations for each exogenous hormone

One-way analysis of variance ANOVA indicated that mean total root length was significantly influenced by exogenous hormone application. Maximum mean total root length was found in IBA $750 \mathrm{mg} / \mathrm{L}(82 \mathrm{~cm})$ which was significantly $(\mathrm{F}(6,14)=38$, $p=0.0000)$ higher than control. Total root length in IBA increased continuously and 
reached its peak at $750 \mathrm{mg} / \mathrm{L}$ and then decreased. NAA had also an obvious trend, as it increased continuously and reached its peak at $1000 \mathrm{mg} / \mathrm{L}$ with $67 \mathrm{~cm}$ mean total root length and then decreased. IAA significantly showed higher mean total root length at $1000 \mathrm{mg} / \mathrm{L}(50 \mathrm{~cm})$ compared to control $(16 \mathrm{~cm})$. Among all four plant growth regulator types, GGR 6 showed very low root length. Results showed that $\mathrm{GGR}_{6}$ had similar mean total root length to its control at $750 \mathrm{mg} / \mathrm{L}$ (Fig. 3 b).

Root diameter was observed almost the same in all treatments. Among all exogenous hormone types, $\mathrm{GGR}_{6}$ at $250 \mathrm{mg} / \mathrm{L}$ showed highest mean root diameter $(1.57 \mathrm{~mm})$ and indicated the significant results $((\mathrm{F}(6,14)=7.98, p=0.0007)) . \mathrm{GGR}_{6}$ at $500 \mathrm{mg} / \mathrm{L}$ showed significantly same mean root diameter $(1.18 \mathrm{~mm})$ to its control and then continuously decreased and reached to $0.53 \mathrm{~mm}$ at $1250 \mathrm{mg} / \mathrm{L}$ concentration. NAA $750 \mathrm{mg} / \mathrm{L}$ showed the highest mean root diameter $(1.5 \mathrm{~mm})$ among its all concentrations and control. IBA $250 \mathrm{mg} / \mathrm{L}$ significantly showed $1.5 \mathrm{~mm}$ mean root diameter. IBA $1500 \mathrm{mg} / \mathrm{L}$ significantly showed the lowest root diameter $(0.98 \mathrm{~mm})$. According to ANOVA, IAA showed non-significant results. IAA $250 \mathrm{mg} / \mathrm{L}$ showed a $1.54 \mathrm{~mm}$ root diameter which was non-significant to all its concentrations and control (Fig. 3c).

The application of plant growth regulators triggered and enhanced the root volume. Among all PGRs and their concentrations, IBA showed significant trend because IBA at $750 \mathrm{mg} / \mathrm{L}$ significantly $((\mathrm{F}(6,14)=10.8, p=0.0001))$ showed highest mean root volume $\left(1.19 \mathrm{~cm}^{3}\right)$ compared to all other exogenous hormone concentrations and its control group. Mean root volume trend was not obvious in NAA application because increasing and decreasing trend was found. NAA at $1000 \mathrm{mg} / \mathrm{L}$ showed maximum root volume $\left(0.87 \mathrm{~cm}^{3}\right)$. IAA showed highest root volume at $750 \mathrm{mg} / \mathrm{L}\left(0.6 \mathrm{~cm}^{3}\right)$ which was not higher than IBA and NAA applications. IAA $1000 \mathrm{mg} / \mathrm{L}$ and $1500 \mathrm{mg} / \mathrm{L}$ showed non-significant results. GGR 6 showed low root volume compared to all other exogenous hormone applications. $\mathrm{GGR}_{6}$ at $1000 \mathrm{mg} / \mathrm{L}$ showed the highest mean root volume $\left(0.46 \mathrm{~cm}^{3}\right)$ which was non-significant to 750 and $500 \mathrm{mg} / \mathrm{L}$ concentrations. Lowest mean root volume was found in $1250 \mathrm{mg} / \mathrm{L}\left(0.09 \mathrm{~cm}^{3}\right)$ which was non-significant to its control application (Fig. 3d).

\section{Principal component analysis}

For the screening and evaluation of exogenous hormones and to provide a comprehensive analysis, the principal component analysis was performed on the first experiment. The variance and variance cumulative rate of each component is shown in Table 2. SPSS extracted two components along with their eigenvalues. The cumulative contribution of the two principal components is $94.387 \%$.

Table 2. Variance cumulative contribution rate of each composition

\begin{tabular}{c|c|c|c|c|c|c}
\hline \multirow{2}{*}{ Components } & \multicolumn{3}{|c|}{ Initial Eigenvalue } & \multicolumn{3}{c}{ Extracted sum square } \\
\cline { 2 - 7 } & Total & $\begin{array}{c}\text { Variance } \\
(\boldsymbol{\%})\end{array}$ & $\begin{array}{c}\text { Accumulation } \\
(\boldsymbol{\%})\end{array}$ & Total & $\begin{array}{c}\text { Variance } \\
(\boldsymbol{\%})\end{array}$ & $\begin{array}{c}\text { Accumulation } \\
(\boldsymbol{\%})\end{array}$ \\
\hline 1 & 3.880 & 77.609 & 77.609 & 3.880 & 77.609 & 77.609 \\
2 & 0.839 & 16.778 & 94.387 & 0.839 & 16.778 & 94.387 \\
3 & 0.126 & 2.529 & 96.916 & & & \\
4 & 0.086 & 1.730 & 98.645 & & & \\
5 & 0.068 & 1.355 & 100.000 & & & \\
\hline
\end{tabular}


Two principal component expressions and the formulas of the comprehensive scoring are sorted out as follows:

$$
\begin{gathered}
C 1=0.0965 \times 1+0.0958 \times 2+0.0954 \times 3+0.0471 \times 4+0.948 \times 5 \text { (Eq.2) } \\
C 2=-0.032 X 1-1.20 X 2-0.2 X 3+0.881 X 4-0.083 X 5 \\
C=\frac{\lambda_{1} c_{1}+\lambda_{2} c_{2}}{\lambda_{1}+\lambda_{m}}
\end{gathered}
$$

Among the formulas given above, $\mathrm{C}_{1}$ indicates the main component 1 score while $C_{2}$ indicates the main component 2 score. $C$ indicates the comprehensive score and $\mathrm{X}_{1}$ to $\mathrm{X}_{5}$ indicates rooting rate, total root length, number of roots, root diameter and root volume respectively. $\lambda_{1}$ and $\lambda_{2}$ indicate the variance of main component 1 and main component 2 respectively and it is known from Table 5 that $\lambda_{1}=77.609$ and $\lambda_{2}=16.778$.

The five rooting parameters values are substituted into Equations 2, 3 and 4. The score and ranking of each treatment are listed in Table 3. According to the comprehensive ranking among four exogenous hormone treatments, the application of IBA to propagate Magnolia biondii Pamp has a better overall effect, especially at the concentration of $750 \mathrm{mg} / \mathrm{L}$.

Table 3. Principal component scores and comprehensive scores of each process

\begin{tabular}{c|c|c|c|c}
\hline & C1 & C2 & C & Rank \\
\hline IBA 750 & 2.671 & -0.217 & 2.158 & 1 \\
IBA 1000 & 1.668 & 0.001 & 1.372 & 2 \\
NAA 1000 & 1.338 & 0.223 & 1.140 & 3 \\
NAA 750 & 1.076 & 0.913 & 1.047 & 4 \\
IBA 500 & 1.251 & -0.463 & 0.946 & 5 \\
IBA 250 & 0.689 & 1.019 & 0.748 & 6 \\
NAA 500 & 0.788 & 0.202 & 0.684 & 7 \\
IBA 1250 & 0.746 & -0.336 & 0.553 & 8 \\
NAA 250 & 0.252 & 0.535 & 0.302 & 9 \\
NAA 1250 & 0.453 & -0.638 & 0.259 & 10 \\
IAA 750 & -0.082 & 0.758 & 0.067 & 11 \\
IBA 1500 & 0.352 & -1.002 & 0.111 & 12 \\
IAA 1000 & -0.009 & 0.132 & 0.016 & 13 \\
IAA 1250 & -0.098 & 0.370 & -0.015 & 14 \\
IAA 500 & -0.249 & 0.535 & -0.110 & 15 \\
NAA 1500 & -0.038 & -0.908 & -0.192 & 16 \\
IAA 1500 & -0.601 & 0.530 & -0.400 & 17 \\
IAA 250 & -0.909 & 1.409 & -0.497 & 18 \\
IBA 0 & -0.853 & 1.045 & -0.515 & 19 \\
GGR 750 & -0.442 & -0.610 & -0.472 & 20 \\
GGR 250 & -1.230 & 1.643 & -0.719 & 21 \\
GGR 500 & -0.848 & 0.037 & -0.691 & 22 \\
NAA 0 & -0.999 & 0.187 & -0.788 & 23 \\
IAA 0 & -1.283 & 0.888 & -0.897 & 24 \\
GGR 1000 & -0.594 & -1.460 & -0.748 & 25 \\
GGR 0 & -1.086 & 0.049 & -0.885 & 26 \\
GGR 1500 & -0.991 & -2.329 & -1.229 & 27 \\
GGR 1250 & -0.972 & -2.514 & -1.246 & 28 \\
\hline
\end{tabular}




\section{Stem cuttings collected from the different positions of the tree crown}

Analysis of variance indicated that cuttings collected from different position of the tree crown significantly affected all rooting parameters. All the rooting parameters either continuously increased or continuously decreased according to the position of the tree crown. The highest rooting rate was achieved with the cuttings collected from the lower part of the tree crown. Table 4 depicted that rooting rate varied from $19.0 \%$ (upper position) to $79.67 \%$ (lower position), whereas the number of roots ranged from 1.73 to 22 roots from the upper part to the lower part of the tree crown respectively. Total root length also significantly increased from upper position to middle and then highest total root length $(113.67 \mathrm{~cm})$ was found in the lower position of the tree crown. Root diameter showed significantly different results from all other rooting parameters. Maximum mean root diameter $(1.41 \mathrm{~mm})$ was achieved in the upper position of the tree crown while lowest mean root diameter $(1.03 \mathrm{~mm})$ was found in the lower position of the tree crown, and significant results were achieved $(\mathrm{F}(2,6)=11.1, p=0.0096)$. Root volume showed an obvious trend, increased from upper position to the lower position of the crown. It showed the mean root volume of $0.28 \mathrm{~cm}^{3}$ at the upper position and $1.08 \mathrm{~cm}^{3}$ at the lower position of the crown.

Table 4. The effects of the cuttings taken from different positions of the trees on the rooting

\begin{tabular}{c|c|c|c|c|c}
\hline Tree crown & RR $(\%)$ & NR $(\mathbf{p c s})$ & TRL $(\mathbf{c m})$ & RD $(\mathbf{m m})$ & $\mathbf{R V}_{\left(\mathbf{c m}^{\mathbf{3}}\right)}$ \\
\hline Upper & $19.00 \pm 1.52^{\mathbf{c}}$ & $1.73 \pm 0.27^{\mathbf{c}}$ & $17.40 \pm 1.28^{\mathbf{c}}$ & $1.41 \pm 0.05^{\mathbf{a}}$ & $0.28 \pm 0.03^{\mathbf{b}}$ \\
Middle & $63.33 \pm 0.66^{\mathbf{b}}$ & $11.12 \pm 1.17^{\mathbf{b}}$ & $74.87 \pm 2.94^{\mathbf{b}}$ & $1.11 \pm 0.07^{\mathbf{b}}$ & $0.90 \pm 0.13^{\mathbf{a}}$ \\
Lower & $79.67 \pm 2.33^{\mathbf{a}}$ & $22.04 \pm 1.65^{\mathbf{a}}$ & $113.67 \pm 4.93^{\mathbf{a}}$ & $1.03 \pm 0.04^{\mathbf{b}}$ & $1.08 \pm 0.02^{\mathbf{a}}$ \\
\hline
\end{tabular}

Values followed by the same letters show non-significant differences while different letters show significant differences $\left(\mathrm{LSD}_{0.05}\right)$ for each rooting parameter at different crown position. RR indicates the rooting rate, NR number of roots, TRL total root length, RD root diameter, and RV indicates root volume. Data are mean $\pm \mathrm{SE}$

\section{Effect of cuttings immersion time into the exogenous hormone}

The rooting rate varied significantly between different immersion time periods of cuttings into the exogenous hormone ( $\mathrm{P}<0.05$, ANOVA) (Table 5). Maximum rooting rate $(80.67 \%$ ) was achieved in the cuttings treated with IBA $750 \mathrm{mg} / \mathrm{L}$ for $120 \mathrm{~min}$, while the minimum rooting rate was found $62.67 \%$ for 360 min. Cuttings treated for $60 \mathrm{~min}$ also yielded $77.33 \%$ rooting which is non-significant to $120 \mathrm{~min}$ treatment. The maximum number of roots were found in the cuttings treated for $120 \mathrm{~min}$ ( 27.21 roots), while the minimum number of roots were found in the cuttings treated for $360 \mathrm{~min}$ (15.47 roots). Total root length, root diameter, and root volume had no significant differences for different immersion time.

\section{The effect of different cuttings length on the rooting}

In this study, four-length classes of the cuttings were used to check their effect on the rooting. Our results revealed that the length of the cuttings significantly affected the rooting rate, number of roots, total root length and root volume, while no significant effect was found in root diameter (Table 6). Direct relation was found between the length of the cuttings and rooting rate. Maximum rooting rate $(83.11 \%)$ was found in the cuttings having 21-25 cm length while the minimum rooting rate was found in 5- 
$10 \mathrm{~cm}$ long cuttings $(49.33 \%)$. Cuttings of class length $21-25 \mathrm{~cm}$ produced the highest number of roots (29.67), while the lowest number of roots were found in 5-10 cm length class cuttings (8.83). The highest total root length and root volume were also found in the longer cuttings $(21-25 \mathrm{~cm})$. In case of root diameter, non-significant results were found $(\mathrm{F}(3,8)=1.30, p=0.34))$. Maximum root diameter $(1.26 \mathrm{~mm})$ was found in the cuttings having the length of $11-15 \mathrm{~cm}$ while minimum root diameter $(1.06 \mathrm{~mm})$ was found in $16-20 \mathrm{~cm}$ long cuttings.

Table 5. The effect of different time of immersion of the cuttings into the exogenous hormone on the rooting

\begin{tabular}{c|c|c|c|c|c}
\hline Time $(\mathbf{m i n})$ & RR $(\%)$ & NR $(\mathbf{p c s})$ & TRL $(\mathbf{c m})$ & RD $(\mathbf{m m})$ & RV $(\mathbf{c m 3})$ \\
\hline 60 & $77.33 \pm 2.90^{\mathrm{a}}$ & $24.52 \pm 0.86^{\mathrm{a}}$ & $116.85 \pm 1.16^{\mathrm{a}}$ & $1.24 \pm 0.09^{\mathrm{a}}$ & $1.15 \pm 0.10^{\mathbf{a}}$ \\
120 & $80.67 \pm 2.33^{\mathrm{a}}$ & $27.21 \pm 0.99^{\mathrm{a}}$ & $111.58 \pm 4.61^{\mathrm{a}}$ & $1.19 \pm 0.09^{\mathrm{a}}$ & $1.21 \pm 0.23^{\mathrm{a}}$ \\
240 & $73.33 \pm 4.80^{\mathrm{ab}}$ & $26.73 \pm 3.57^{\mathrm{a}}$ & $109.77 \pm 2.63^{\mathrm{a}}$ & $1.12 \pm 0.08^{\mathrm{a}}$ & $0.99 \pm 0.06^{\mathbf{a}}$ \\
360 & $62.67 \pm 5.36^{\mathbf{b}}$ & $15.47 \pm 1.42^{\mathbf{b}}$ & $106.71 \pm 5.28^{\mathrm{a}}$ & $1.15 \pm 0.04^{\mathrm{a}}$ & $1.02 \pm 0.23^{\mathrm{a}}$ \\
\hline
\end{tabular}

Values followed by the same letters show non-significant differences while different letters show significant differences $\left(\mathrm{LSD}_{0.05}\right)$ for each rooting parameter at different immersion times. RR indicates the rooting rate, NR number of roots, TRL total root length, RD root diameter, and RV indicates root volume. Data are mean $\pm \mathrm{SE}$

Table 6. The effect of different lengths of the cuttings on the rooting

\begin{tabular}{c|c|c|c|c|c}
\hline Cutting length $(\mathbf{c m})$ & RR $(\%)$ & NR (pcs) & TRL $(\mathbf{c m})$ & RD (mm) & RV (cm3) \\
\hline $5-10$ & $49.33 \pm 2.60^{\mathbf{c}}$ & $8.83 \pm 1.60^{\mathbf{c}}$ & $35.24 \pm 1.93^{\mathbf{d}}$ & $1.10 \pm 0.10^{\mathbf{a}}$ & $0.71 \pm 0.05^{\mathbf{b}}$ \\
$11-15$ & $55.81 \pm 2.94^{\mathbf{c}}$ & $12.21 \pm 1.50^{\mathbf{c}}$ & $73.94 \pm 1.68^{\mathbf{c}}$ & $1.26 \pm 0.02^{\mathbf{a}}$ & $1.20 \pm 0.12^{\mathbf{a}}$ \\
$16-20$ & $68.22 \pm 2.61^{\mathbf{b}}$ & $19.00 \pm 1.92^{\mathbf{b}}$ & $86.51 \pm 1.87^{\mathbf{b}}$ & $1.06 \pm 0.09^{\mathbf{a}}$ & $1.09 \pm 0.09^{\mathbf{a}}$ \\
$21-25$ & $83.11 \pm 1.73^{\mathbf{a}}$ & $29.67 \pm 0.88^{\mathbf{a}}$ & $108.99 \pm 5.87^{\mathbf{a}}$ & $1.14 \pm 0.06^{\mathbf{a}}$ & $1.21 \pm 0.04^{\mathbf{a}}$ \\
\hline
\end{tabular}

Values followed by the same letters show non-significant differences while different letters show significant differences $\left(\mathrm{LSD}_{0.05}\right)$ for each rooting parameter at different cutting lengths. RR indicates the rooting rate, NR number of roots, TRL total root length, RD root diameter, and RV indicates root volume. Data are means $\pm \mathrm{SE}$

\section{Discussion}

Adventitious rooting responses differently to different plant growth regulators. The previous findings also showed that exogenous hormones applications have apparent effects on rooting rate (Zhang et al., 2017; Sevik and Guney, 2013). The process of adventitious rooting is influenced by the number of internal and external factors (Kester et al., 1990; Kumar et al., 2009). Among the internal factors, the most important role is explained by the phytohormones, especially the auxins. These phytohormones cause the cells to change their elasticity, and as result cells absorb more water and energy that leads to more cell division. Therefore, it is generally accepted that auxins have a key role in the process of root initiation (Štefančič et al., 2005).

Among the different exogenous hormones such as GGR6, NAA, IBA, and IAA are known to accelerate the rooting parameters in vegetative propagation through cuttings (Gehlot et al., 2014; Ibrahim et al., 2015). Therefore, in our study, we found the distinct differences in rooting rate, number of roots, total root length, root diameter and root volume due to different exogenous hormones application in the rooting of Magnolia 
biondii Pamp cuttings. It was also found that cuttings treated with IBA treatment induce early and better root initiation. Therefore, the maximum rooting rate and number of roots were found at $750 \mathrm{mg} / \mathrm{L}$ concentration of IBA. The exogenous application of IBA has been reported to enhance cell division and to speed up the translocation and movement of carbohydrates and nutrients to the base of stem cuttings and enhances root growth (Kester et al., 1990; Aminah et al., 1995; OuYang et al., 2015b). These findings are also supported by the previous findings of Kester et al., 1990 that also found similar results in many herbaceous perennial crops. Similarly, in other plant species such as Lippia javanica L. (Soundy et al., 2008) and V. paradoxa and C.F. Gaerth (Akakpo et al., 2014), highest rooting was attained when stem cuttings were treated with IBA. In the case of total root length, we also found that cuttings of Magnolia biondii Pamp treated with IBA $750 \mathrm{mg} / \mathrm{L}$ showed improved root length and it might be because of early cells differentiation and elongation. Moreover, exogenous application of hormones initiates the synthesis of structural enzyme protein in the formation of the adventitious root leading to increase the root length through the acidification process (Kaushik, 2017). Similar conclusions were found by Sharma (2014) in Marigold, Swamy et al. (2002) in Grewia optiva and Robinia pseudoacacia, Grewal et al. (2005) Dendranthema grandiflora cv. Snowball and Singh et al. (2013) in Night Jasmine. Root diameter and volume are also an important factor for the development of a newly developed seedling to keep its root system stronger to reach its climax stage during the early development. Therefore, application of exogenous hormones helps the plants to develop stronger and thicker roots during the early developmental stage.

In the literature, auxins were found better to develop more thick roots and as a result, the root diameter is increased (Bhatt and Tomar, 2011). We also found the prominent effects of auxins (NAA, IBA, IAA) and gibberellin (GGR6), but compared to auxins, the gibberellin $\left(\mathrm{GGR}_{6}\right)$ had a relatively better effect in the root diameter (Liu et al., 2005). Because the gibberellins are the third most commonly used plant hormones with a share of $17 \%$. The most commonly used commercial gibberellin is $\mathrm{GGR}_{6}$. It is mostly used for increasing the height of a plant or flower yield (Kumlay and Eryigit, 2011), but in our study GGR 6 significantly affected the root diameter compared to auxin group of hormones and to the control, that is consistent with the results provided by Liu et al. (2013) that GGR 6 treated cuttings had higher root diameter values than other exogenous hormones. While, in the case of root volume, IBA had a significant effect on the cuttings. The root volume is also one of the essential parameters used for the evaluation of root morphology. Root volume reflects the quality of root growth, larger the volume of the root, more the developed root system will be (Jie, 2012). Exogenous hormones application plays a vital role in the rooting of the different plant species. Many studies have shown that exogenous application of hormones results in the increased initiation of lateral roots (Chhun et al., 2003). The effect of hormones on rooting and plant development have been discussed in several studies, for example, Kesari et al. (2009) studied the effect of IBA, NAA and IAA on the rooting of Pongamia pinnata and found the maximum rooting rate in IBA treated cuttings. Similarly, Tchinda et al. (2013) conducted a series of experiments by using NAA and IBA for the propagation of Ricinodendron heudelotti Baill species. Sevik and Güney (2013) also studied the rooting potential of Melissa officinalis L. species through stem cuttings using IAA, NAA, IBA, and $\mathrm{GA}_{3}$. Thus, these studies showed that, in general, the exogenous hormones have an effect on rooting and their results are in conformity with the results of our study. We found that through the whole experiment, cuttings treated with 
exogenous hormones respond significantly towards the percent rooting. The differential response of the stem cuttings on various exogenous hormones has been ascribed to the chemical nature of the hormones and the mode of concentrations (Das, 2006). Our results were not impressive in all other hormone types other than IBA. Kester et al., 1990, mentioned that IBA could be used for general use because it is non-toxic to plants over varied concentrations than other auxins. To some extent, NAA also performed well compared to $\mathrm{GGR}_{6}$ and IAA. This reveals that application of $\mathrm{GGR}_{6}$ and IAA exhibits poor root ability and are unable to respond well in Magnolia biondii Pamp. Poor development of roots inhibits the success of vegetative propagation via stem cuttings (De Klerk, 2002). It was also found that, with the increase in exogenous hormone application, rooting also increased and then after reaching its peak value, it decreased with increase in concentration. Kester et al., 1990 mentioned that the higher concentration of exogenous hormones deters the initiation and elongation of roots and stimulates plant cell to produce ethylene.

After the successful screening of best hormone and its best concentration (IBA-750) for the rooting then it was combined with other factors for the optimization of successful propagation treatments the best results of rooting in Magnolia biondii Pamp cuttings. In this regard, first of all, we investigated how the time of soaking improved the rooting. We found that increasing the time of soaking (120 min) of cuttings into IBA $750 \mathrm{mg} / \mathrm{L}$ significantly increased the rooting and affected the rooting morphological characteristics of Magnolia biondii Pamp. Different time of soaking of the cuttings into the IBA significantly affected the rooting and it had various impacts on the morphological characteristics of Magnolia biondii Pamp cuttings which are in agreement with the finding of Panwar et al. (1999) and OuYang et al. (2015a), who studied the effect of exogenous hormones, length of the stem cuttings, and soaking time of the cuttings on the rooting of Norway spruce. Application of IBA $750 \mathrm{mg} / \mathrm{L}$ for 120 min significantly increased rooting rate, number of roots and root volume, while 60 min application enhanced total root length and root diameter. Maximum time application i.e. $360 \mathrm{~min}$ did not have good results which are in agreement to the previous results, who mentioned for Rosa species that, cuttings immersed for $360 \mathrm{~min}$ in IBA concentrations inhibited the rooting. Different environmental factors can influence and there can be variability in the results when cuttings are immersed for a long time period (Kester et al., 1990).

Cuttings of Magnolia biondii Pamp treated with IBA-750, and the best time of soaking was further evaluated to get the best results of rooting. We selected the three positions of the crown i.e., upper, middle and lower. Because the differences existed between the position of the crown on the donor plant for rooting percentage and other parameters (Fishel et al., 2003). We found that maximum rooting percentage was observed in the cuttings taken from the lower part of the crown. Similar results were found during the rooting process of jack pine when the cuttings were collected from the lower position of the crown, they significantly rooted more than the middle and upper position of the crown (Browne et al., 1996). Browne et al. (1996) studied that plant crown position play an important role in the rooting process, lower crown to the middle position of the crown typically show higher rooting frequency than the upper position of the crown. It has been extensively studied that cutting size can often be attributed to the origin of cuttings within and between shoots, and to its position within the stock plant (Leakey, 2004). In most of the tree species, rooting ability of cuttings has been reported to increase from the basal part of the tree crown that attributed to the accumulation of 
carbohydrates (Kester et al., 1990). The effect of crown position on rooting may be caused by the variation in the physiological status of cuttings on stock plants (Kester et al., 1990).

Furthermore, we investigated how the length of the cuttings can be more effective in the propagation of Magnolia biondii Pamp species. So, for this purpose, we explored the IBA-750 with the best time of soaking and crown position to evaluate the effect of cuttings length on the rooting. In our study, significant rooting results were obtained for longer cuttings $(21-25 \mathrm{~cm})$. Longer cuttings rooted at a higher percentage than shorter cuttings and similar results were found in Ayous (Triplochiton scleroxylon) (Leakey, 1983; Leakey and Mohammed, 1985). The effectiveness of rooting by longer cuttings can be explained by different factors. The first factor is that the level of endogenous Auxins and other rooting-inducing factors may be lower in shorter cuttings, which leads to the reduced rooting percentage or the absence of rotting in shorter cuttings (Palanisamy and Kumar, 1997). The second factor is that longer cuttings store more carbohydrates (Tchoundjeu and Leakey, 1996), the carbohydrates of sugars (soluble carbohydrates) and storage carbohydrates (starches or insoluble carbohydrates) are important to rooting as building blocks of complex macromolecules, structural elements, and energy sources (Sturve, 1981; Haissig, 1984, 1986). So, these cuttings use the stored carbohydrates in root regeneration (Kester et al., 1990).

\section{Conclusion}

A protocol for vegetative propagation of Magnolia biondii Pamp was optimized with subsequent development of plants using stem cuttings as source material. The stem cuttings pretreated with exogenous hormone IBA $750 \mathrm{mg} / \mathrm{L}$, time of soaking for 120 min, the position of the parent plant crown (lower position) and longer cuttings of $21-25 \mathrm{~cm}$ significantly affected on the rooting in the greenhouse conditions. This optimized protocol can ease to propagate Magnolia biondii Pamp and can be used to develop healthier and more profuse root system for the propagation and more clone plants. Further studies can be carried out in-depth by using morpho-anatomical studies and antioxidant activities to provide a more effective and feasible method of propagation for Magnolia biondii Pamp species.

Acknowledgments. This research was financially supported by the Special Fund for Forest Scientific Research in the Public Welfare under grant no. 201504704.

\section{REFERENCES}

[1] Akakpo, D. B., Amissah, N., Yeboah, J., et al. (2014): Effect of indole 3-butyric acid and media type on adventitious root formation in sheanut tree (Vitellaria paradoxa CF Gaertn.) stem cuttings. - American Journal of Plant Sciences 5: 313.

[2] Aminah, H., Dick, J. M., Leakey, R., et al. (1995): Effect of indole butyric acid (IBA) on stem cuttings of Shorea leprosula. - Forest Ecology and Management 72: 199-206.

[3] Azamal, H., Mohinder, P. (2000): Analytical studies on the effects of interaction with respect to position, season and auxin on adventitious root formation in stem cuttings of mature teak (Tectona grandis Linn. f.). - Annals of Forestry 8: 253-261.

[4] Bellini, C., Pacurar, D. I., Perrone, I. (2014): Adventitious roots and lateral roots: similarities and differences. - Annual Review of Plant Biology 65: 639-666. 
[5] Bhatt, B. B., Tomar, Y. (2011): Effect of IBA and growing conditions on vegetative performance of Citrus aurantifolia (Swingle) cuttings. - Journal of Hill Agriculture 2: 98101.

[6] Browne, R., Davidson, C., Gobin, S. M. (1996): Effects of crown position and plant age on rooting of jack pine long shoot cuttings. - Tree Planters' Notes 47: 100-104.

[7] Chhun, T., Taketa, S., Tsurumi, S., et al. (2003): The effects of auxin on lateral root initiation and root gravitropism in a lateral rootless mutant Lrt1 of rice (Oryza sativa L.). - Plant Growth Regulation 39: 161-170.

[8] Coombes, A. J. (2014): The Book of Leaves: A Leaf-by-Leaf Guide to Six Hundred of the World's Great Trees. - University of Chicago Press, Chicago.

[9] Das, N. (2006): Propagation prospects of dye yielding plant, Rhinacanthus nasutus (Linn.) Kurz. - Natural Product Radiance 5(1): 42-43

[10] Davies Jr., F. (1988): Influence of nutrition and carbohydrates on rooting of cuttings. Comb. Proc. Int. Plant. Propag. Soc. 432-437.

[11] Davis, T., Haissig, B. (1990): Chemical control of adventitious root formation in cuttings. - Quarterly-PGRSA 18:1-17.

[12] De Klerk, G.-J. (2002): Rooting of microcuttings: theory and practice. - In Vitro Cellular \& Developmental Biology-Plant 38: 415-422.

[13] Dettmer, J., Elo, A., Helariutta, Y. (2009): Hormone interactions during vascular development. - Plant Molecular Biology 69: 347.

[14] Dirr, M. A. (1989): Rooting response of Photinia $\times$ fraseri Dress 'Birmingham' to 25 carrier and carrier plus IBA formulations. - Journal of Environmental Horticulture 7: 158-160.

[15] Elhaak, M., Matter, M., Zayed, M., et al. (2015): Propagation principles in using indole3-butyric acid for rooting rosemary stem cuttings. - Journal of Horticulture. DOI: 10.4172/2376-0354.1000121.

[16] Fishel, D., Zaczek, J., Preece, J. (2003): Positional influence on rooting of shoots forced from the main bole of swamp white oak and northern red oak. - Canadian Journal of Forest Research 33: 705-711.

[17] Gehlot, A., Gupta, R. K., Tripathi, A., et al. (2014): Vegetative propagation of Azadirachta indica: effect of auxin and rooting media on adventitious root induction in mini-cuttings. - Advances in Forestry Science 1: 1-9.

[18] Geiss, G., Gutierrez, L., Bellini, C. (2009): Adventitious root formation: new insights and perspectives. - Annual Plant Reviews 37: 127-156.

[19] Grewal, H., Kumar, R., Chauhan, R. (2005): Effect of IB A and N AA on rooting in chrysanthemum (Dendrantlwma grandiflora Tzevlev) terminal cuttings. - Journal of Ornamental Horticulture 8: 230-232.

[20] Haissig, B. E. (1984): Carbohydrate accumulation and partitioning in Pinus banksiana seedlings and seedling cuttings. - Physiologia Plantarum 61: 13-19.

[21] Haissig, B. E. (1986): Metabolic Processes in Adventitious Rooting of Cuttings. - In: Jackson, M. B. (ed.) New Root Formation in Plants and Cuttings. Springer, Dordrecht, pp. 141-189.

[22] Harrison-Murray, R., Knight, L. (1997): New Approaches to Optimising Environments for Rooting Cuttings. - Combined Proceedings-International Plant Propagators Society. Univ Washington, Int Plant Propagation Soc, pp. 206-210.

[23] Ibrahim, M., Mohamed, M., Khalid, K. (2015): Effect of plant growth regulators on the rooting of lemon verbena cutting. - Journal of Materials and Environmental Science 6: 28-33.

[24] Jamir, S. L., Deb, C. R., Jamir, N. S. (2016): Macropropagation and production of clonal planting materials of Panax pseudoginseng Wall. - Open Journal of Forestry 6: 135.

[25] Jie, J. (2012): Effects of IBA and 6-BA on the Growth of Roots and Aboveground Branches of Transplanted. - Nanjing Agricultural University, Nanjing. 
[26] Kaushik, S. (2017): Effect of IBA and NAA and Their Combination on Rooting in Stem Cuttings of African Marigold (Tagetes erecta L.) CV. Pusa Narangi Gainda. - Indira Gandhi Krishi Vishwavidhyalaya, Raipur.

[27] Kesari, V., Krishnamachari, A., Rangan, L. (2009): Effect of auxins on adventitious rooting from stem cuttings of candidate plus tree Pongamia pinnata (L.), a potential biodiesel plant. - Trees 23: 597-604.

[28] Kester, D., Davies, F., Hartmann, H. (1990): Plant Propagation: Principles and Practices. - Prentice-Hall, India.

[29] Kumar, B., Lakshman, K., Jayaveera, K., et al. (2009): Estimation of rutin and quercetin in Terminalia chebula by HPLC. - Asian Journal of Research in Chemistry 2: 388-389.

[30] Kumlay, A., Eryigit, T. (2011): Growth and development regulators in plants: plant hormones. - Igdir University Journal of the Institute of Science and Technology 1: 47-56.

[31] Leakey, R. (1983): Stockplant factors affecting root initiation in cuttings of Triplochiton scleroxylon K. Schum., an indigenous hardwood of West Africa. - Journal of Horticultural Science 58: 277-290.

[32] Leakey, R., Mohammed, H. (1985): The effects of stem length on root initiation in sequential single-node cuttings of Triplochiton scleroxylon K. Schum. - Journal of Horticultural Science 60: 431-437.

[33] Leakey, R. R. (2004): Physiology of Vegetative Reproduction. - Academic Press Cambridge, MA.

[34] Lekha, G., Lalji, S. (2010): Study of factors influencing vegetative propagation of Jatropha curcas. - Indian Forester 136: 1637-1648.

[35] Liu, G.-F., Song, X.-B., Xu, Y.-H., et al. (2005): A study on role of GGR6 in seedlingraising of Taxus chinensis var. mairei. - Forest Research-Chinese Academy of Forestry 18: 730 .

[36] Liu, K.-C., Yu, Y.-P., Wang, L.-H., et al. (2013): Effects of three plant growth regulators on the root growth of Erythrophleum fordii. - Northern Horticulture 5.

[37] Luz, P. B. d., Paiva, P. D. d. O., Landgraf. P. R. C. (2007): Influence of different types of stem cuttings and substrates on the asexual reproduction of hydrangea (Hydrangea macrophylla) (Thunb.). - Ser. Ciência e Agrotecnologia 31: 699-703.

[38] OuYang, F., Junhui, W., Li, Y. (2015a) Effects of cutting size and exogenous hormone treatment on rooting of shoot cuttings in Norway spruce [Picea abies (L.) Karst.]. - New Forests 46: 91-105.

[39] OuYang, F., Wang, J., Li, Y. (2015b) Effects of cutting size and exogenous hormone treatment on rooting of shoot cuttings in Norway spruce [Picea abies (L.) Karst.]. - New Forests 46: 91-105.

[40] Palanisamy, K., Kumar, P. (1997): Effect of position, size of cuttings and environmental factors on adventitious rooting in neem (Azadirachta indica A. Juss). - Forest Ecology and Management 98: 277-280.

[41] Panwar, R., Gupta, A., Yamdagni, R., et al. (1999): Effect of growth regulators on the rooting of cuttings of Bougainvillea cv. Thimma. - Haryana Agric Univ J Res 29: 11-17.

[42] Papp, B., Plath, K. (2011): Reprogramming to pluripotency: stepwise resetting of the epigenetic landscape. - Cell Research 21: 486.

[43] Sevik, H., Guney, K. (2013): Effects of IAA, IBA, NAA, and GA3 on rooting and morphological features of Melissa officinalis L. stem cuttings. - The Scientific World Journal. https://doi.org/10.1155/2013/909507.

[44] Sevik, H., Turhan, H. (2015): Effects of IBA (indole butiric acide) on rooting and newly stem to Turkish lili (Lilium martagon L.) onion. - ICONSETE Conference Austria Proceedings Book, Vienna.

[45] Sharma, R. (2014): Study on the Effect of Auxins on Rooting, Growth and Flowering of African Marigold (Tagetes Erecta L.) Propagated Through Stem Cuttings. - Indira Gandhi Krishi Vishwavidyalaya, Raipur. 
[46] Singh, K., Rawat, V., Rawat, J., et al. (2013): Effect of IBA and NAA concentrations on rooting in stem cuttings of night queen (Cestrum nocturnum $\mathrm{L}$ ) under sub-tropical valley conditions. - HortFlora Research Spectrum 2: 81-83.

[47] Soundy, P., Mpati, K. W., du Toit, E. S., et al. (2008): Influence of cutting position, medium, hormone and season on rooting of fever tea (Lippia javanica L.) stem cuttings. Medicinal and Aromatic Plant Science and Biotechnology 2: 114-116.

[48] Štefančič, M., Štampar, F., Osterc, G. (2005): Influence of IAA and IBA on root development and quality of Prunus' GiSelA 5'leafy cuttings. - HortScience 40: 20522055.

[49] Sturve, D. (1981): The relation between carbohydrates, nitrogen and rooting of stem cuttings. - The Plant Propagator 27: 6-7.

[50] Swamy, S., Puri, S., Singh, A. (2002): Effect of auxins (IBA and NAA) and season on rooting of juvenile and mature hardwood cuttings of Robinia pseudoacacia and Grewia optiva. - New Forests 23: 143-157.

[51] Tchinda, N., Messi, H., Fotso, et al. (2013): Improving propagation methods of Ricinodendron heudelotti Baill. from cuttings. - South African Journal of Botany 88: 3-9.

[52] Tchoundjeu, Z., Leakey, R. (1996): Vegetative propagation of African mahogany: effects of auxin, node position, leaf area and cutting length. - New Forests 11: 125-136.

[53] Villacorta-Martín, C., Sánchez-García, A. B., Villanova, J., et al. (2015): Gene expression profiling during adventitious root formation in carnation stem cuttings. - BMC Genomics 16: 789.

[54] Wang, Q., Weijian, F., Shen, Y. (2017): Three kinds of magnolia full light cutting propagation technology. - Seed 36(3): 128-129.

[55] Zhang H., Charles, R. Z., Wang, J. (2003): Magnolia and Wangchun Yulan all-light spray twig cutting test. - Shaanxi Forestry Science and Technology 4: 22-23.

[56] Zhang, W., Fan, J., Tan, Q., et al. (2017): The effects of exogenous hormones on rooting process and the activities of key enzymes of Malus hupehensis stem cuttings. - PloS One 12: e0172320. 